\title{
Studi Numerik Karakteristik Perpindahan Panas pada Membrane Wall Tube Boiler Dengan Variasi Jenis Material dan Ketebalan Insulasi di PLTU Unit 4 PT.PJB UP Gresik
}

\author{
I Nyoman Ari Susastrawan D dan Prabowo. \\ Jurusan Teknik Mesin, Fakultas Teknologi Industri, Institut Teknologi Sepuluh Nopember (ITS) \\ Jl. Arief Rahman Hakim, Surabaya 60111 Indonesia \\ e-mail: prabowo@me.its.ac.id
}

\begin{abstract}
Abstrak-Salah satu komponen terpenting dalam siklus pembangkit listrik bertenaga uap adalah boiler, dimana fungsi utama dari komponen ini adalah penghasil steam (uap) yang akan menggerakan turbin guna menghasilkan tenaga listrik. Proses pemanasan yang terjadi di dalam boiler memiliki suhu yang sangat tinggi, dimana suhu yang dihasilkan bisa mencapai $1000^{\circ} \mathrm{C}$ - $2000^{\circ} \mathrm{C}$. Sesuai dengan hukum perpindahan panas, kondisi ini akan berpotensi menghasilkan kehilangan panas yang sangat besar. Peningkatan efisiensi pada boiler telah banyak diteliti, salah satunya dengan menggunakan material insulasi untuk menghindari kerugian akibat kehilangan panas (Heatloss). Material yang digunakan untuk insulasi pada pipa adalah material yang mempunyai nilai konduktivitas thermal rendah, tahan pada temperatur tinggi, instalasi mudah dan tidak korosif. Penelitian ini bertujuan untuk mengetahui distribusi temperatur dan nilai heatloss pada membrane wall tube dengan memvariasikan ketebalan insulasi dan jenis material insulasi yang digunakan. Membrane wall tube akan disimulasikan secara 2 Dimensi dengan menggunakan prinsip Computational Fluid Dynamic (CFD) Variasi yang digunakan antara lain: ketebalan insulasi; temperature steam; jenis material insulasi (high temperature insulation) menggunakan Rockwool dan Glasswool. Ketebalan juga ikut mempengaruhi besar heatloss yang terjadi dimana semakin tebal lapisan insulasinya maka semakin rendah nilai heatlossnya. Selain itu perubahan temperatur steam tidak memberikan pengaruh yang signifikan, namun dalam penelitian ini semakin tinggi temperatur steam maka nilai heatlossnya akan semakin kecil. Penelitian ini juga menunjukan pengaruh radiasi lebih mendominasi pengaruh konveksi, meski demikian pengaruh keduanya tidak dapat diabaikan karena sangat berpengaruh dalam proses perpindahan panas. Desain yang paling optimum dalam penelitian ini ialah insulasi rockwool dengan ketebalan 90 mm.
\end{abstract}

Kata Kunci : insulasi; radiasi; distribusi temperature; heatloss; ketebalan optimum.

\section{PENDAHULUAN}

$\mathrm{P}$ ERINDUSTRIAN di Indonesia kini semakin maju dan berkembang seiring dengan pesatnya perkembangan dunia teknologi. Sehubungan dengan hal tersebut, maka akan semakin besar pula kebutuhan listrik yang merupakan infrastruktur primer dari sebuah Negara. Dan sebagai kebutuhan pokok bagi tiap orang tanpa memandang golongan dan status sosialnya, diperlukan pasokan listrik yang harus memadai kebutuhan suatu Negara[1]. Guna menopang segala sarana dan pra sarana dari sektor perindustrian di Indonesia, kebutuhan listrik merupakan sesuatu yang sangat vital dan harus dipenuhi.

PLTU sebagai salah satu jenis pembangkit yang paling sering dijumpai di Indonesia merupakan suatu sistem pembangkit yang saling terkait antara satu komponen dengan komponen lainnya. Salah satu komponen terpenting dalam siklus pembangkit ini adalah boiler, dimana fungsi utama dari komponen ini adalah penghasil steam (uap) yang akan menggerakan turbin guna menghasilkan tenaga listrik[2]. Air yang mengalir di dalam membrane wall tube pada boiler dipanaskan oleh panas dari hasil pembakaran bahan bakar (sumber panas lainnya) di dalam ruang bakar (furnace) sehingga terjadi perpindahan panas dari sumber panas tersebut ke air yang mengakibatkan air tersebut menjadi panas atau berubah wujud menjadi uap.

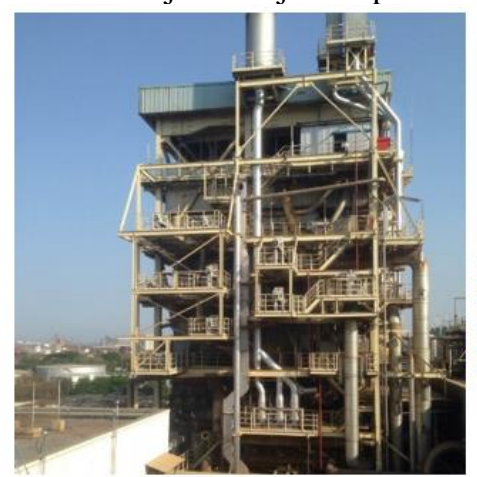

(a)

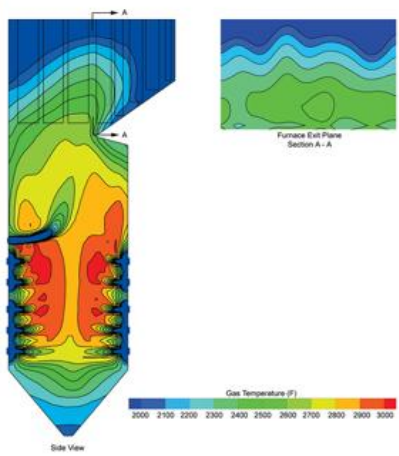

(b)
Gambar 1. (a) Boiler pada PLTU Gresik (b) Distribusi Temperatur pada Boiler [3]

Proses pemanasan yang terjadi di dalam boiler memiliki suhu yang sangat tinggi, dimana suhu nya dihasilkan bisa mencapai $1000^{\circ} \mathrm{C}-2000^{\circ} \mathrm{C}$ untuk memanaskan air yang mengalir pada membrane tube [3]. Jenis material dari tube - tube yang digunakan pada Pembangkit Listrik Tenaga Uap merupakan material yang memiliki nilai konduktivitas tinggi, hal ini dilakukan dengan harapan perpindahan panas yang terjadi secara konveksi dan radiasi dari panas yang dihasilkan di dalam furnace ke air di dalam tube bisa terdistribusi lebih baik dan temperaturnya tetap tinggi. Namun dari proses ini akan terjadi pertukaran panas dari lingkungan yang temperaturnya jauh lebih rendah dengan uap panas di dalam membrane tube yang memiliki temperatur yang lebih tinggi. Hal ini akan menyebabkan temperatur uap panas pada membrane tube turun 
dan panas yang hilang (heatloss) akan semakin besar. Akibatnya efisiensi dari boiler akan turun.

Penelitian ini bertujuan untuk menyelesaikan permasalahan tersebut, untuk itu perlu dilakukan insulasi di sekeliling dinding ruang bakar. Hal ini bertujuan untuk menjaga temperatur uap panas yang mengalir pada membrane tube tetap tinggi dan meminimalkan heatloss. Material yang digunakan untuk insulasi pada pipa adalah material yang mempunyai nilai konduktivitas termal rendah, tahan pada temperatur tinggi, instalasi mudah, harga murah dan tidak korosif.

\section{METODE PENELITIAN}

Peneliltian ini dilakukan dengan mengunakan analisa simulasi numerik secara dua dimensi dengan menggunakan perangkat lunak berbasis Computational Fluid Dynamic (CFD) untuk proses pembuatan domain dan iterasi. Sebelum dilakukan proses simulasi, terlebih dahulu perlu ditentukan daerah mana yang akan diteliti. Adapun daerah yang diteliti untuk kemudian disimulasikan ditunjukan pada gambar 2 dan keterangan geometri ditampilkan pada tabel 1 .

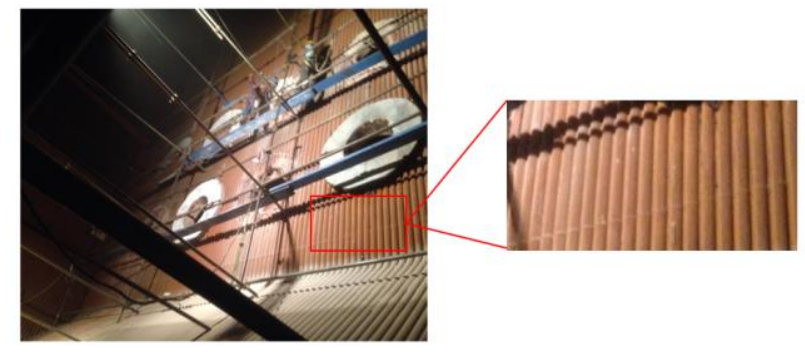

Gambar 2. Lokasi dari Sampel Membrane tube yang akan Disimulasikan

Pada penelitian ini daerah yang diteliti terletak di area bagian membrane wall tube yang berlokasi tepat disisi bagian bawah burner lips seperti yang ditunjukan pada gambar 2. Hal ini dilakukan karena bagian ini dianggap menerima panas yang paling tinggi saat proses pembakaran di ruang bakar (furnace).

Tabel 1

Geometri Membrane tube dan Insulasi

\begin{tabular}{|c|c|}
\hline Dimensi & Value \\
\hline \multicolumn{2}{|c|}{ Membrane Wall Tube } \\
\hline Thickness (mm) & 7.9 \\
\hline Diameter inside (mm) & 60.4 \\
\hline Diameter Outside (mm) & 76.2 \\
\hline \multicolumn{2}{|c|}{ Insulation } \\
\hline Thickness (mm) & $50 \mathrm{~mm} \mathrm{~s} / \mathrm{d} 180 \mathrm{~mm}$ \\
\hline
\end{tabular}

Prosedur yang dilakukan pada penelitian secara numerik dibagi menjadi 3 tahap utama, antara lain:

A. Pre-processing

Pada tahap ini dilakukan input data, antara lain pembuatan geometri model, domain, meshing dan boundary type, seperti ditampilkan pada gambar 3 untuk domain dan gambar 4 untuk meshing. Tahap ini dilakukan menggunakan perangkat lunak CFD komersial dengan Meshing model existing dan variasi temperature steam seperti yang ditunjukkan pada tabel 2.

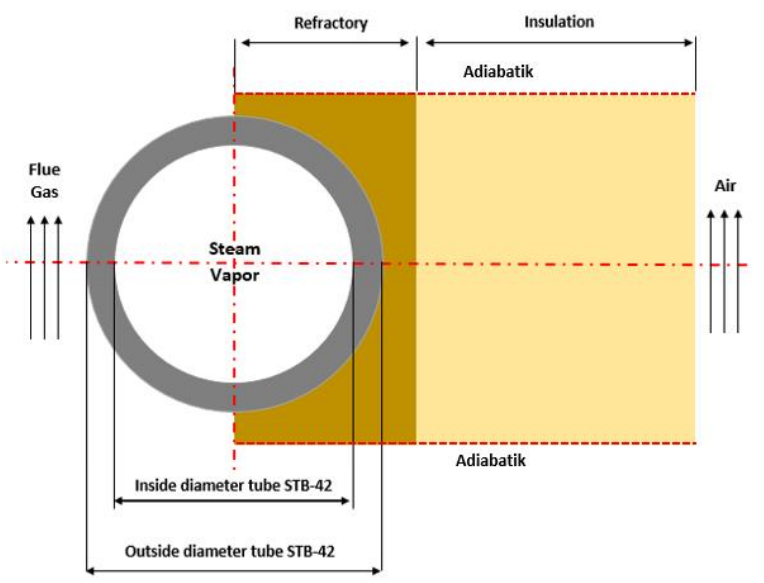

Gambar 3. Domain membrane tube dan insulasi

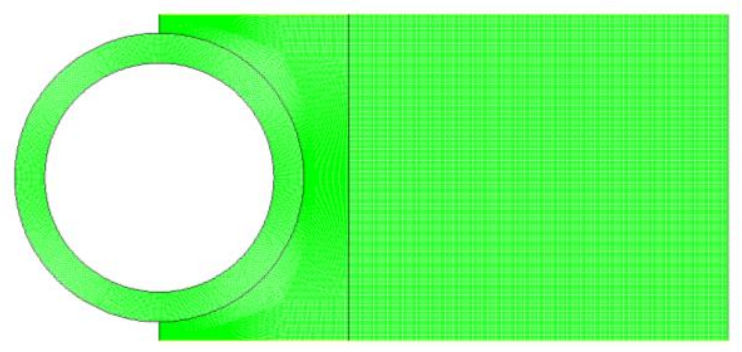

Gambar 4. Meshing untuk Membrane tube dan Insulasi dengan bentuk Quadrilateral-map

\section{B. Processing}

Tahap kedua dilakukan menggunakan perangkat lunak CFD komersial dengan jenis solver yang dipilih berupa keakuratan ganda 2D. Solusi yang dilakukan berupa second order dan properties flue gas yang dimodelkan sebagai gas ideal dan steam yang dimodelkan sebagai water vapor dengan kondisi steady, ditampilkan pada tabel 3.

Tabel 2

Boundary Condition pada Membrane tube

\begin{tabular}{|c|l|}
\hline Boundary Condition & \multicolumn{1}{|c|}{ Keterangan } \\
\hline \multirow{5}{*}{ Outside Tube } & Tipe: Stationary Wall \\
& Material: STB-42 \\
& Thermal condition: Convection and \\
& Radiation \\
& Free Stream Temperature: $1500 \mathrm{~K}$ \\
& Heat Transfer Coefficient : $31 \mathrm{~W} / \mathrm{mK}$ \\
& External Radiation Temperature: $1500 \mathrm{~K}$ \\
& Emisivitas flue gas: 0.2 \\
\hline \multirow{5}{*}{ Inside Tube } & Tipe: Stationary Wall \\
& Material: STB-42 \\
& Thermal condition: Convection \\
& Free Stream Temperature: \\
& 400K; 450K; dan 500K \\
\hline Insulasi lapisan & Tipe: Stationary Wall \\
pertama & Material: Refractory \\
& Thermal condition: Coupled \\
\hline \multirow{3}{*}{ Insulasi lapisan } & Tipe: Stationary Wall \\
kedua & Material: Rockwool dan Glasswool \\
& Thermal condition : Convection \\
& Free stream Temperature: $300 \mathrm{~K}$ \\
\hline
\end{tabular}




\section{Post-processing}

Hasil simulasi numerik secara kualitatif dianalisa berdasarkan visualisasi kontur temperatur. Secara kuantitatif, data hasil iterasi diolah menjadi grafik distribusi temperatur, perbandingan nilai heatloss untuk masing - masing model variasi.

- Analisa Heatloss dan Ketebalan Optimum

Dengan menggunakan analisa perpindahan panas secara radiasi, konveksi dan konduksi maka nilai heatloss dapat dicari:

1. Perpindahan Panas secara Radiasi

Nilai heatloss perpindahan panas secara radiasi dapat dicari menggunakan rumus:

$q_{\text {rad }}=\varepsilon \sigma\left(T_{s}^{4}-T_{\text {sur }}^{4}\right)[1]$

Atau dapat menggunakan rumus ketahanan thermal pada dinding silinder dengan rumus:

$R_{\text {rad }}=\frac{1}{2 \pi r L h_{r}}[\mathbf{1}]$

Dimana nilai $\mathrm{h}_{\mathrm{r}}$ (koefisien radiasi) dapat dicari dengan menggunakan rumus:

$h_{r}=\varepsilon \sigma\left(T_{s}+T_{\text {sur }}\right)\left(T_{s}^{2}+T_{\text {sur }}^{2}\right)[1]$

2. Perpindahan Panas secara Konveksi

a) External Flow

Nilai heatloss perpindahan panas secara konveksi pada aliran external dapat dicari dengan menggunakan rumus rumus:

$q_{\text {conv }}=h A\left(T_{s}-T_{\infty}\right)[1]$

Atau dapat menggunakan rumus ketahanan

thermal pada dinding silinder dengan rumus

$R_{\text {conv }}=\frac{1}{2 \pi r L h_{\text {conv }}}[\mathbf{1}]$

Mencari nilai h (koefisien konveksi) pada aliran external dapat menggunakan rumus rumus:

$\overline{N u}_{D}=\frac{\bar{h} D}{k}=C \cdot \operatorname{Re}_{D}^{m} \operatorname{Pr}^{1 / 3} ; \operatorname{Re}=\frac{\rho \cdot V \cdot D_{\text {outside }}}{\mu} ; V=\frac{\dot{m}}{\rho \times A}$

[2]

b) Internal Flow

Mencari nilai h (koefisien konveksi) pada aliran internal dapat menggunakan rumus rumus:

$\overline{N u}_{D}=\frac{\bar{h} D}{k}=0.023 \cdot \operatorname{Re}_{D}^{4 / 5} \operatorname{Pr}^{n} ; R e=\frac{4 \dot{m}}{\pi \mu D_{\text {inside }}}[2]$

3. Perpindahan panas secara Konduksi

Nilai heatloss perpindahan panas secara radiasi dapat dicari menggunakan rumus:

$q_{\text {cond }}=k A \frac{T_{2}-T_{1}}{L}[1]$

Atau dapat menggunakan rumus ketahanan thermal pada dinding silinder dengan rumus:

$R_{\text {rad }}=\frac{\ln \left(r^{2} / r 1\right)}{2 \pi k L}[1]$

4. Thermal Resistance Total:

$\mathrm{R}_{\text {total: }} \mathrm{R}$ radiasi pembakaran $+\mathrm{R}$ konveksi pembakaran $+\mathrm{R}$ konduksi pipa

$+\mathrm{R}$ konveksi steam $+\mathrm{R}$ konduksi refractory $+\mathrm{R}$ konduksi insulasi +

$\mathrm{R}$ konveksi lingkungan [1]

5. Mencari nilai Heatloss Total:

$q_{\text {tot }}=\frac{\Delta T}{\text { Rtot }}[\mathbf{1}]$

6. Mencari ketebalan optimum dari perbandingan biaya insulasi dan kerugian akibat heatloss:

Biaya akibat heatloss $=$ Heatloss $\times$ jam kerja pertahun $\times$ harga gas

\section{URAIAN PENELITIAN}

Pada penelitian ini berfokus untuk mengetahui pengaruh ketebalan, jenis material insulasi, temperature steam pada membrane tube dan proses perpindahan panas secara konveksi dan radiasi. Hasil yang ditampilkan berupa pengolahan data hasil simulasi CFD dalam bentuk kuantitatif dan kualitatif. Data kuantitatif akan disajikan dalam bentuk grafik dan tabel, sedangkan data kualitatif akan disajikan dalam bentuk visualisasi kontur distribusi temperatur.

1. Analisa Heatloss dan Ketebalan Optimum Insulasi pada Membrane tube

a) Analisa Nilai Heatloss pada Membrane tube

Grafik nilai heatloss untuk insulasi glasswool dengan variasi Tsteam: (a) 400K; (b) 450K; dan (c) $500 \mathrm{~K}$ ditunjukan pada gambar 8 .

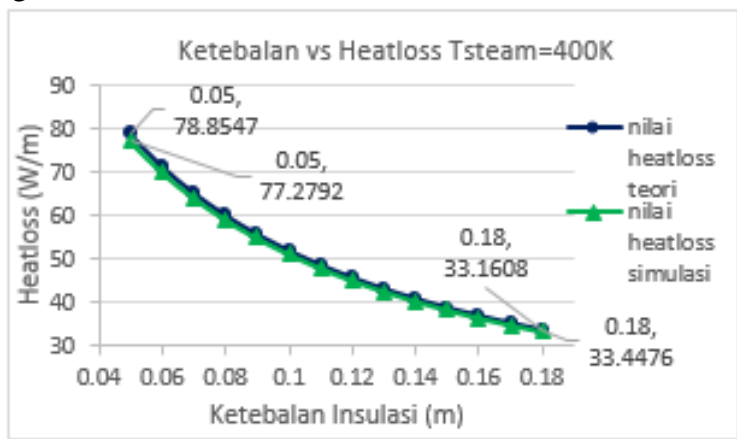

(a)

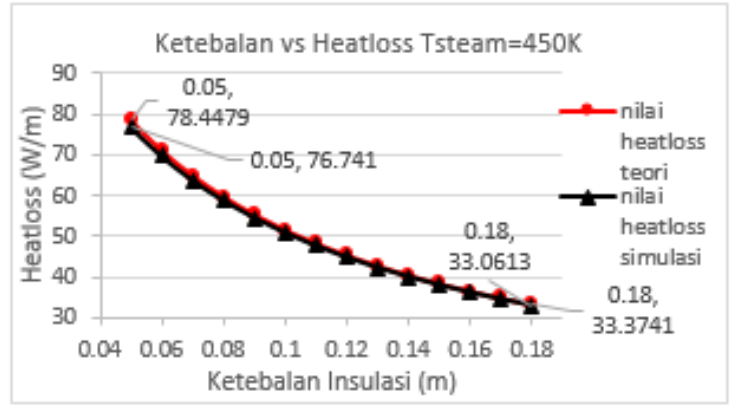

(b)

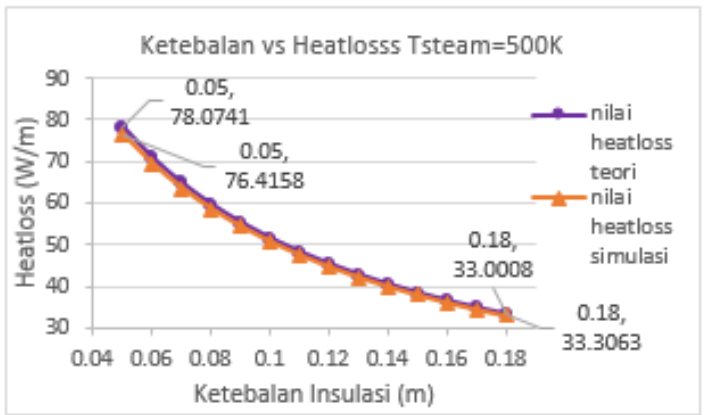

(c)

Gambar 8. Ketebalan Insulasi vs Heatloss Membrane tube Pada Kondisi Pembebanan: (a)Tsteam=400K; (b)Tsteam $=450 \mathrm{~K}$; dan (c)Tsteam $=500 \mathrm{~K}$ Dengan Menggunakan Lapisan Glasswool

Gambar 8 menunjukan keseragaman trendline ditiap variasi pembebanan bahwa nilai heatloss terbesar terjadi ketika lapisan insulasi nya sebesar $50 \mathrm{~mm}$ dan heatloss terkecil terendah terjadi ketika lapisan insulasi nya sebesar $180 \mathrm{~mm}$.

Sedangkan grafik nilai heatloss untuk insulasi rockwool dengan variasi Tsteam: (a) $400 \mathrm{~K}$; (b) $450 \mathrm{~K}$; dan (c) $500 \mathrm{~K}$ ditunjukan pada gambar 9 . 


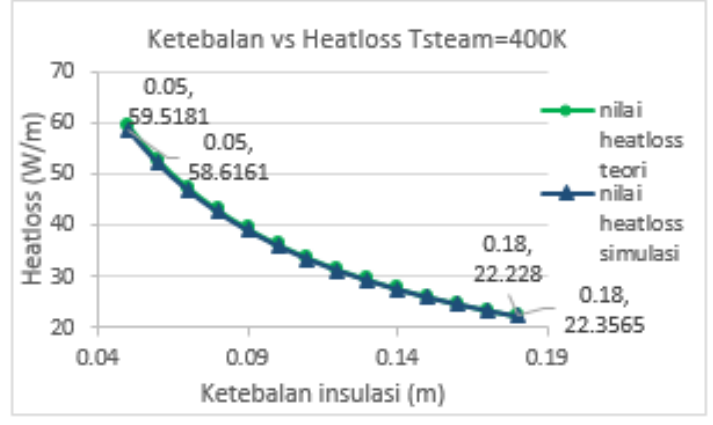

(a)

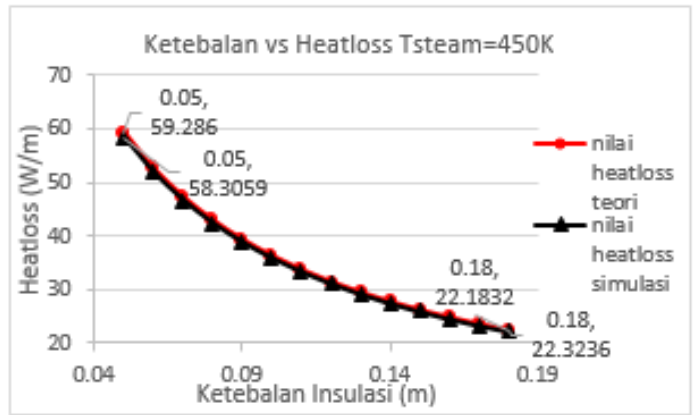

(b)

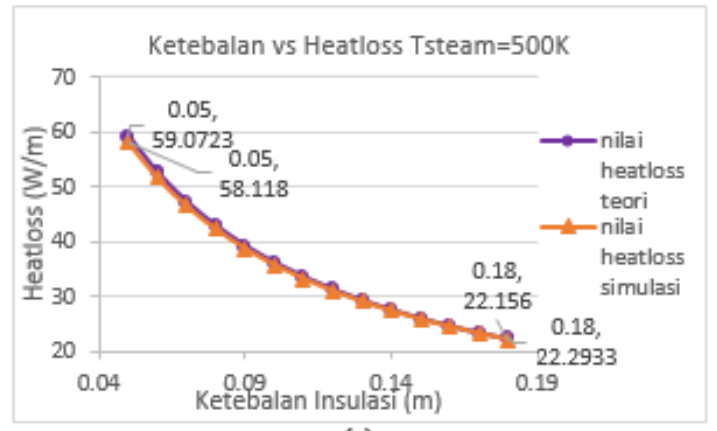

(c)

Gambar 9. Ketebalan Insulasi vs Heatloss Membrane tube Pada Kondisi Pembebanan: (a)Tsteam=400K; (b)Tsteam $=450 \mathrm{~K}$; dan (c)Tsteam $=500 \mathrm{~K}$ Dengan Menggunakan Lapisan Rockwool

Gambar 9 juga menunjukan keseragaman trendline ditiap variasi pembebanan bahwa nilai heatloss terbesar terjadi ketika lapisan insulasinya sebesar $50 \mathrm{~mm}$ dan heatloss terkecil terendah terjadi ketika lapisan insulasinya sebesar $180 \mathrm{~mm}$. dari kedua gambar tersebut dapat diketahui jika variasi pembebanan temperatur kerja dari steam yang mengalir di dalam membrane tube tidak memberikan perbedaan yang signifikan terhadap trendline nilai heatloss baik pada jenis insulasi glasswool maupun rockwool. Dari hasil perhitungan dan grafik ini dapat diketahui semakin kecil nilai temperatur kerja dari steam maka semakin besar nilai heatloss dan besar laju perpindahan panas nya. Sedangkan semakin besar nilai beban temperatur kerja dari steam maka semakin kecil nilai heatloss dan laju perpindahan panas nya.

Fenomena ini dapat terjadi dikarenakan adanya perbedaan nilai temperatur yang besar antara flue gas dengan steam, dan juga steam dengan temperatur lingkungan. Hal ini sesuai dengan teori yang ada, dimana besarnya nilai heatloss dari masing masing proses perpindahan panas dipengaruhi oleh nilai perbedaan temperatur (To - Tsteam) nya [1]. b) Analisa Ketebalan Optimum pada Insulasi Membrane tube

Untuk mengetahui ketebalan paling optimum dari penelitian ini perlu dibandingkan antara kerugian akibat heatloss dan biaya yang dikeluarkan untuk instalasi masing masing jenis insulasi. Grafik ketebalan optimum dari masing masing insulasi ditunjukan pada gambar 10 dan gambar 11.

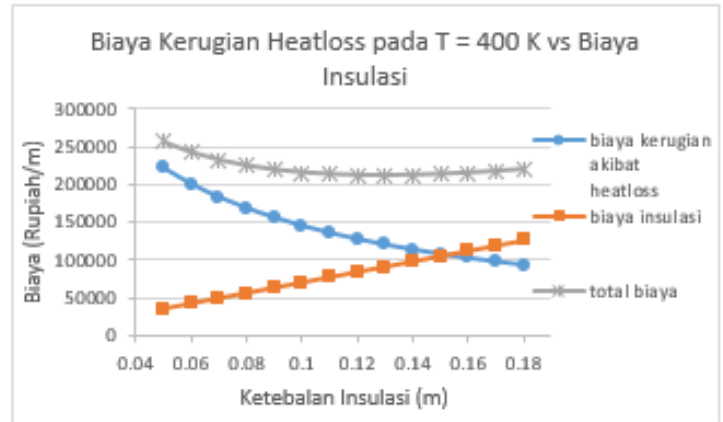

(a)

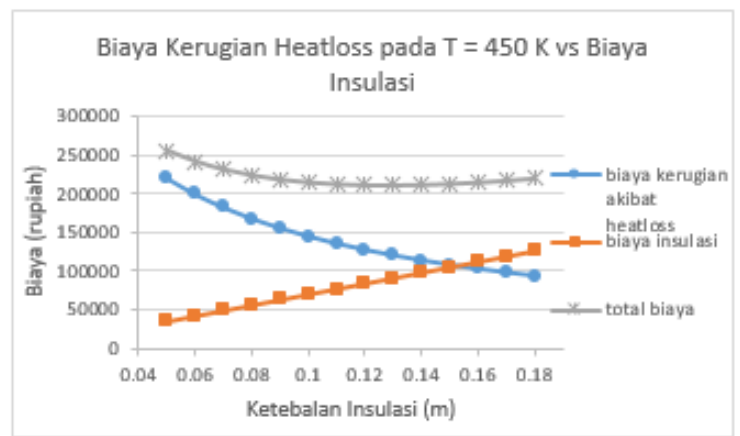

(b)

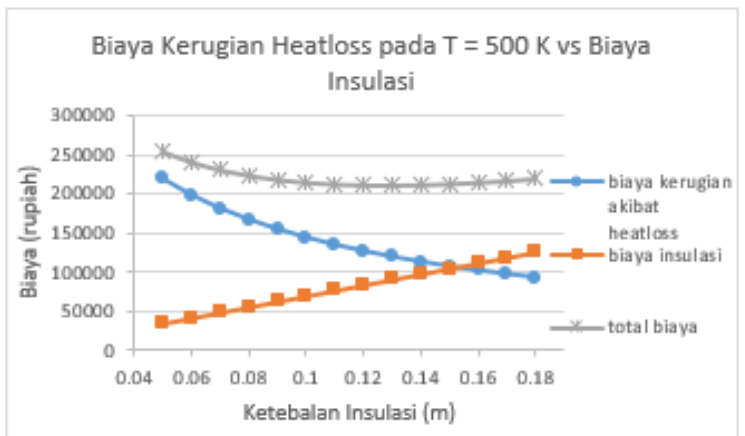

(c)

Gambar 10. Biaya Kerugian Akibat Heatloss per Tahun vs Biaya Insulasi yang Dikeluarkan pada: (a) Tsteam $=400 \mathrm{~K}$ (b) Tsteam $=450 \mathrm{~K}$; dan (c)

Tsteam $=500 \mathrm{~K}$ dengan Menggunakan Lapisan Glasswool

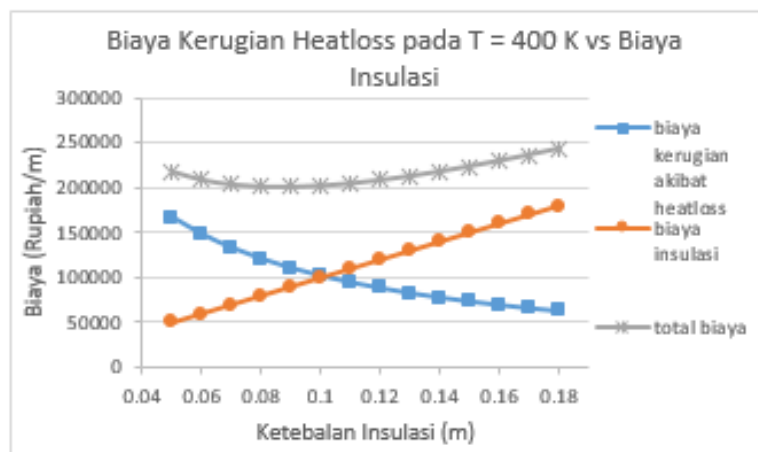

(a) 


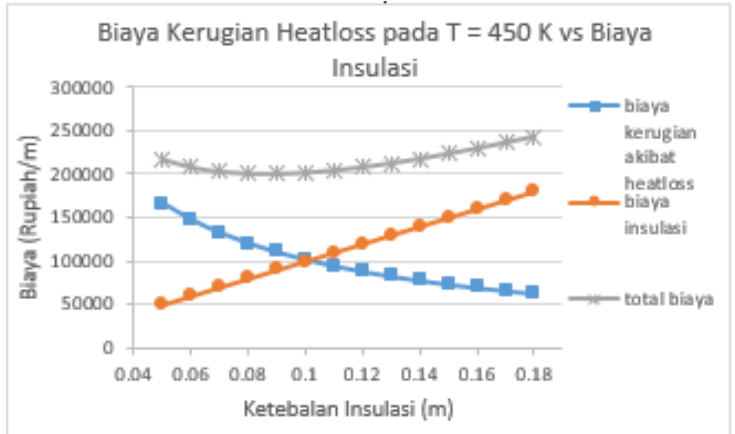

(b)

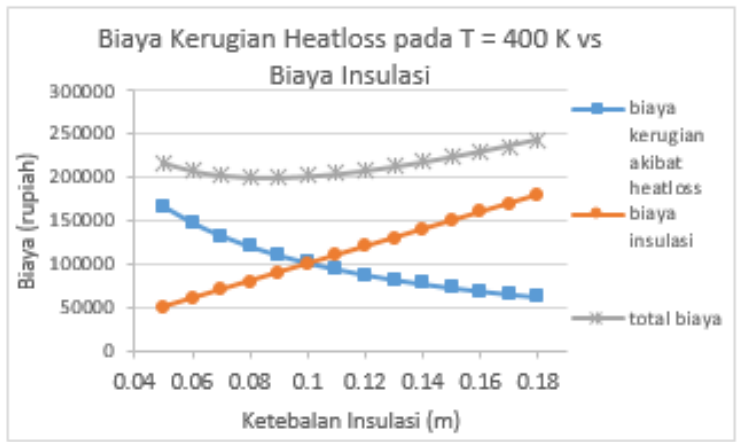

(c)

Gambar 11. Biaya Kerugian Akibat Heatloss per Tahun vs Biaya Insulasi yang Dikeluarkan pada: (a) Tsteam $=400 \mathrm{~K}$ (b) Tsteam $=450 \mathrm{~K}$; dan (c) Tsteam $=500 \mathrm{~K}$ dengan Lapisan Rockwool

Pada gambar 10 dan gambar 11 diketahui bahwa trend grafik biaya insulasi bertambah seiring dengan bertambahnya ketebalan insulasi. Sebaliknya biaya energi yang dikeluarkan akibat kerugian heatloss akan turun dengan penambahan ketebalan insulasi Dari kedua data tersebut didapatkan hubungan keduanya yang menunjukan total biaya dari kerugian heatloss dan biaya insulasi, dimana kedua grafik tersebut bersinggungan di titik $152 \mathrm{~mm}$ untuk jenis insulasi glasswool dan di titik $106 \mathrm{~mm}$ untuk jenis insulasi rockwool. Namun kedua titik persinggungan ini bukan merupakan titik imerupakan titik optimum dari perbandingan biaya kerugian akibat heatloss dengan biaya insulasi, titik optimum pada kasus ini ditunjukan pada trendline total biaya, dimana dapat dilihat bahwa titik optimum terjadi pada ketebalan $130 \mathrm{~mm}$ untuk jenis insulasi glasswool dan $90 \mathrm{~mm}$ untuk jenis insulasi rockwool.

\section{Visualisasi Kontur Temperatur pada Membrane tube dengan} Lapisan Insulasi Rockwool

Setelah dilakukan analisa untuk mengetahui nilai heatloss yang didapatkan dari masing masing jenis insulasi, didapatkan bahwa rockwool memiliki hasil yang lebih baik di bandingkan dengan glasswool. Untuk memperkuat hasil analisa tersebut dilakukan visualisasi kontur temperature dari hasil simulasi. Pada Gambar 12 ditunjukan kontur temperatur pada membrane wall tube dengan insulasi rockwool dengan kondisi Tsteam: (a) $400 \mathrm{~K}$; (b) $450 \mathrm{~K}$; dan (c) $500 \mathrm{~K}$.
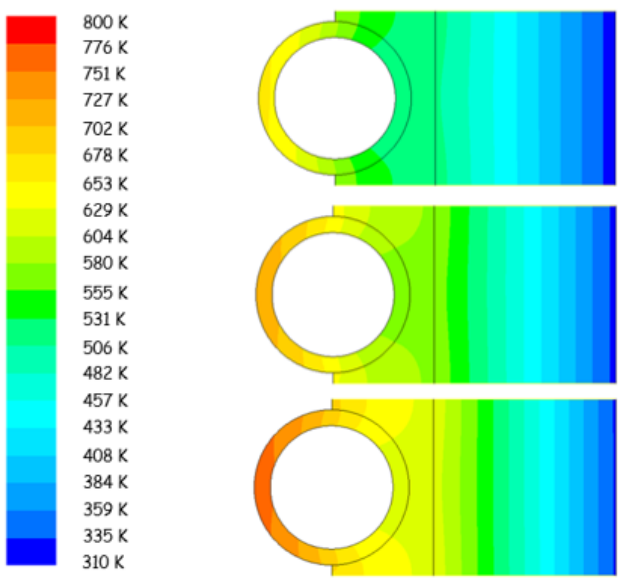

(a)

Gambar 12. Kontur Distribusi Temperatur pada Membrane tube Boiler Menggunakan Lapisan Rockwool dengan Ketebalan 90 mm (a) Tsteam=400K; (b) Tsteam=450K; dan (c) Tsteam $=500 \mathrm{~K}$

Gambar 12. Menunjukan perbedaan temperatur yang ditandai dengan perubahaan warna pada masing masing temperatur steam, dapat dilihat bahwa warna merah menunjukan temperatur tertinggi dan warna biru tua menunjukan temperatur terendah. Pada kondisi T steam $=400$ $\mathrm{K}$ terlihat di sisi depan tubenya berwarna kuning yang berarti nilainya masih lebih rendah jika dibandingkan dengan kondisi $\mathrm{T}$ steam $=450 \mathrm{~K}$ yang sisi depan tubenya berwarna oranye muda. Dan peningkatan terlihat kembali ketika kondisi T steam $=500 \mathrm{~K}$ yang sisi depan tubenya berwarna oranye kemerahan. Di sisi bagian belakang, pada $\mathrm{T}$ steam $=400 \mathrm{~K}$ warna yang ditampilkan adalah hijau kebiruan yang berarti temperaturnya lebih rendah jika dibandingkan dengan $\mathrm{T}$ steam $=450 \mathrm{~K}$ yang memiliki warna hijau muda. Namun temperatur tertinggi dimiliki membrane tube dengan kondisi $\mathrm{T}$ steam $=500 \mathrm{~K}$ terlihat dari warna kuning kehijauan yang menunjukan bahwa sisi bagian belakang tube masih memiliki temperatur yang tinggi. Jadi semakin besar nilai $\mathrm{T}$ steam akan menghasilkan kontur distribusi yang lebih baik. Selisih temperature flue gas dengan temperatur steam yang semakin rendah akan menghasilkan nilai heatloss yang lebih kecil.

\section{Visualisasi Kontur Distribusi Temperatur Pengaruh}

Perpindahan Panas secara Konveksi dan Radiasi pada Membrane Tube dengan Insulasi Rockwool

Dalam proses analisa nya, sering kali salah satu dari dua proses perpindahan panas ini tidak diperhitungkan atau diabaikan. Sehingga dalam penelitian ini akan coba dianalisa bagaimana pengaruh nya ketika salah satu proses perpindahan panas diabaikan dan dibandingkan satu sama lainnya.

Gambar 4.13 menunjukan kondisi pada Tsteam $=400 \mathrm{~K}$; Gambar 4.14 menunjukan kondisi pada Tsteam $=450 \mathrm{~K}$; dan Gambar 4.15 menunjukan kondisi pada Tsteam $=500 \mathrm{~K}$ dimana (a) menunjukan perpindahan panas yang diakibatkan konveksi, sedangkan (b) menunjukan perpindahan panas yang diakibatkan radiasi. Dari kontur ketiga gambar tersebut, terlihat temperatur akibat pengaruh radiasi memiliki temperatur yang jauh lebih tinggi jika dibandingkan dengan temperatur akibat pengaruh konveksi. 

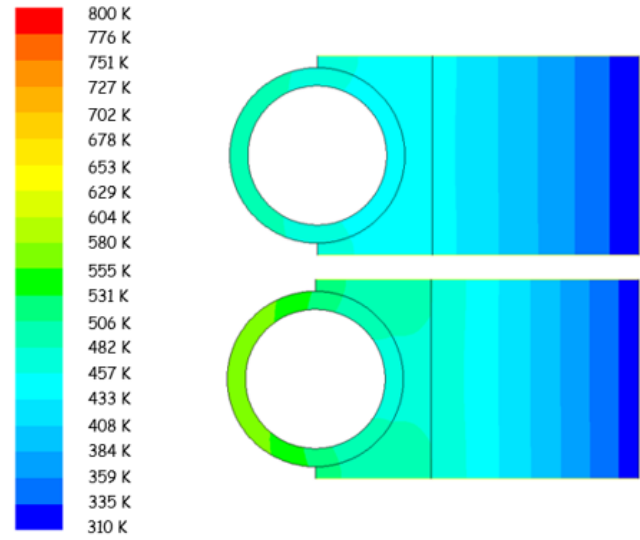

(a)

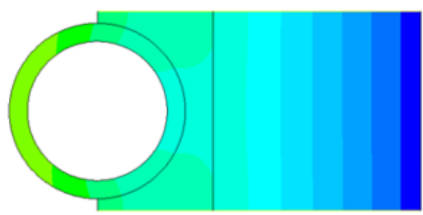

Gambar 13. Kontur Distribusi Temperatur pada Membrane tube Boiler Menggunakan Lapisan Rockwool dengan Ketebalan 90 mm pada Tsteam $=400 \mathrm{~K}$ secara: (a) koveksi; dan (b) radiasi
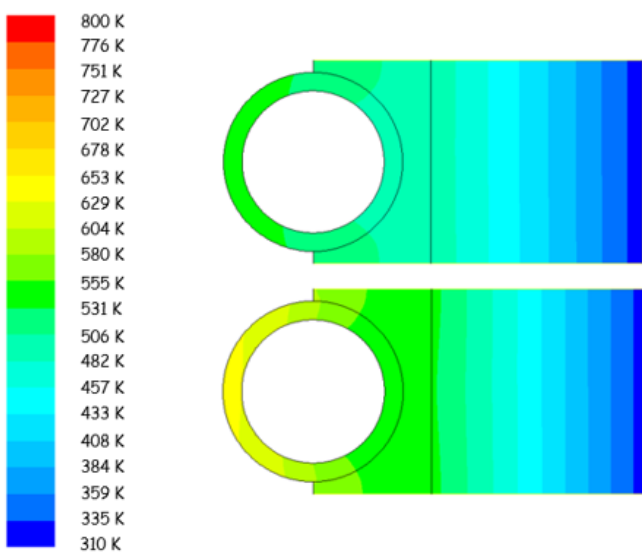

(a)

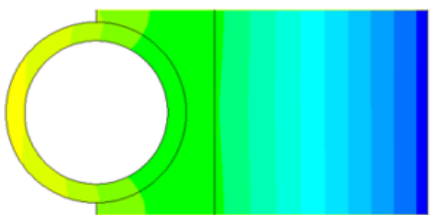

(b)

Gambar 14. Kontur Distribusi Temperatur pada Membrane tube Boiler Menggunakan Lapisan Rockwool dengan Ketebalan 90 mm pada
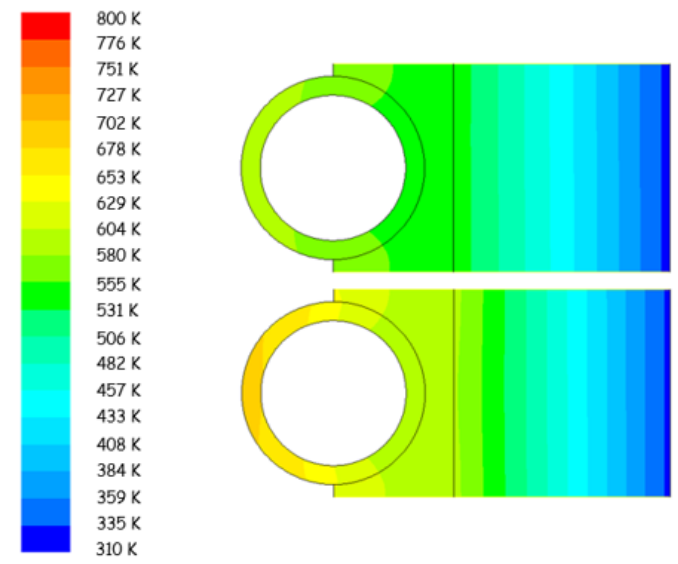

(a)

Gambar 15. Kontur Distribusi Temperatur pada Membrane tube Boiler Menggunakan Lapisan Rockwool dengan Ketebalan 90 mm pada Tsteam $=500 \mathrm{~K}$ secara: (a) koveksi; dan (b) radiasi

Dari ketiga gambar tersebut terlihat pengaruh perpindahan panas akibat radiasi memang lebih mendominasi pengaruh perpindahan panas akibat konveksi. Namun ketika keduanya tidak diabaikan dalam proses analisa, dari hasil simulasi menunjukan temperatur permukaan tube yang dihasilkan akan memiliki nilai yang lebih tinggi. Temperatur permukaan yang semakin tinggi sangat menguntungkan dalam proses pemanasan aliran steam pada membrane tube. Oleh karena itu meskipun radiasi lebih mendominasi jika dibandingkan dengan konveksi, kedua proses perpindahan panas ini jika tidak diabaikan akan menghasilkan distribusi, nilai heatloss dan temperatur permukaan tube yang jauh lebih baik, sehingga kedua nya tidak dapat diabaikan dalam proses perhitungan dan analisa pada penelitian ini.

\section{PENUTUP}

Berdasarkan analisa dan pembahasan yang dilakukan, maka didapatkan beberapa kesimpulan diantaranya:

1. Insulasi rockwool menghasilkan nilai heatloss yang lebih baik dibandingkan dengan insulasi glasswool hal ini dikarenakan nilai konduktivitas dari rockwool lebih rendah dibandingkan dengan konduktivitas glasswool.

2. Semakin tinggi nilai temperatur steam di dalam membrane tube akan menghasilkan nilai heatloss yang lebih kecil. Hal ini dikarenakan semakin tinggi nilai steam maka perbedaan temperaturnya dengan flue gas akan semakin kecil dan membuat proses distribusi panasnya lebih efektif. Nilai heatloss terkecil terjadi pada Temperatur steam 500K.

3. Ketebalan optimum dari insulasi sebesar $90 \mathrm{~mm}$ untuk jenis rockwool dan $130 \mathrm{~mm}$ untuk jenis glasswool.

4. Pada proses perpindahan panas yang terjadi di penelitian ini pengaruh radiasi lebih mendominasi pengaruh konveksi. Meski demikian pengaruh radiasi dan konveksi tetap tidak dapat diabaikan pada proses analisa.

\section{UCAPAN TERIMA KASIH}

Ucapan terima kasih kepada Jurusan Teknik Mesin FTI-ITS yang telah memberikan dukungannya terhadap penelitian ini. Dan ucapan terima kasih kepada pihak PT. PJB UP Gresik yang telah mendukung penulis dalam pengumpulan data dan penyusunan laporan penelitian ini.

\section{DAFTAR PUSTAKA}

[1] Incropera, Frank P. 2007. Fundamentals of Heat and Mass Transfer, $6^{\text {th }}$ edition. New York: John Wiley \& Sons.

[2] Fox, Robert W., Mc Donald, Alan T., dan Pritchard, Philip J. 2010. Introduction to Fluid Mechanics, $7^{\text {th }}$ Edition. New York: John Wiley \& Sons.

[3] Bobcock and Wilcox. 2005 . Steam it's generation and use. USA: Ohio: The Bobcock \& Wilcox Company. 